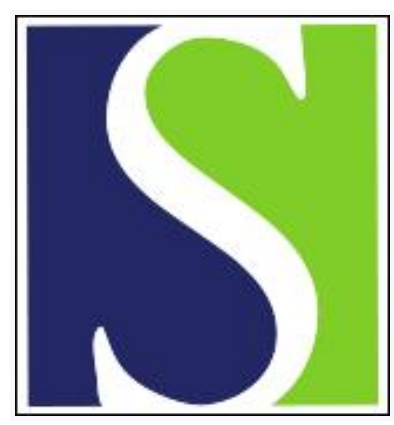

Scand J Work Environ Health 1986;12(6):538-544

https://doi.org/10.5271/sjweh.2103

Issue date: Dec 1986

Mortality and incidence of cancer among Swedish rubber workers, 1952-1981.

by Gustavsson P, Hogstedt C, Holmberg B

The following article refers to this text: 2011;37(4):316-324

This article in PubMed: www.ncbi.nlm.nih.gov/pubmed/3823802

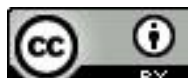




\title{
Mortality and incidence of cancer among Swedish rubber workers, 1952-1981
}

\author{
by Per Gustavsson, MD, ${ }^{1}$ Christer Hogstedt, MD, ${ }^{1,2}$ Bo Holmberg, $\mathrm{PhD}^{3}$
}

\begin{abstract}
GUSTAVSSON P, HOGSTEDT C, HOLMBERG B. Mortality and incidence of cancer among Swedish rubber workers, 1952-1981. Scand J Work Environ Health 12 (1986) 538-544. The mortality and incidence of cancer was studied among 8734 workers from two Swedish rubber manufacturing companies. Mortality was investigated from 1952 to 1981 and cancer incidence from 1959 to 1980 . The expected numbers of deaths were calculated from national statistics. No significant risk excesses were detected when the cohort was analyzed without consideration of employment time or latency period. However, the mortality from coronary heart disease and the incidence of lung cancer were increased when the study period was limited to $\geq 40$ years since first employment. The standardized mortality ratio for coronary heart disease correlated positively with employment duration. The mortality from asthma, bronchitis, and emphysema was nonsignificantly increased. The incidence of bladder cancer was increased among individuals with heavy and long-term exposure in the weighing and mixing departments. Twenty-five percent of the individuals in the cohort were not Swedish citizens at the time of employment, and an analysis of the mortality and cancer incidence in this group showed a markedly increased lung cancer incidence for certain immigrant groups, probably mainly due to ethnic factors. The results indicate that ethnic factors must be considered in the analysis of occupational groups when a high proportion of the workers are immigrants.
\end{abstract}

Key terms: bladder cancer, coronary heart disease, epidemiology, lung cancer, rubber chemicals.

Workers in the rubber industry may be exposed to a wide variety of chemicals - natural and synthetic rubber, rubber additives, dust, organic solvents, and substances formed during the vulcanization process (19). An epidemiologic investigation published in 1954 showed an excess of bladder cancer (6) among rubber workers in the United Kingdom. Exposure to 2-aminonaphthalene, an aromatic amine present in rubber antioxidants as an impurity, was pointed out as the causative agent for bladder cancer (6). Such compounds were abandoned around 1950 in the United Kingdom. Further investigations of the rubber industry in this same country showed an increased frequency of lung cancer and cancer of the gastrointestinal organs $(5,14$, $15,30,32,34)$.

In contrast to the British rubber industry, reports of increased malignancies of the hematopoetic system are frequent from the rubber industry in the United States $(3,24,25,27)$. Increases of bladder cancer $(8$, $27)$, lung cancer $(2,27)$, esophageal cancer $(9)$, and prostatic cancer $(16,24)$ have also been reported. A Swedish record-linkage study of vulcanization workers

1 Department of Occupational Medicine, Karolinska Hospital, S-104 01 Stockholm, Sweden.

2 Section of Occupational Medicine, Research Department, National Board of Occupational Safety and Health, S-171 84 Solna, Sweden.

3 Unit of Occupational Toxicology, Research Department, National Board of Occupational Safety and Health, S-171 84 Solna, Sweden.

Reprint requests to: Dr P Gustavsson, Department of Occupational Medicine, Karolinska Hospital, S-104 01 Stockholm, Sweden. has shown an increased incidence of esophageal cancer (29).

Some rubber additives used in the manufacturing process are mutagenic in bacterial test systems (18), and vulcanization gases also have mutagenic properties $(10,17)$. Biological monitoring of workers in the weighing and mixing departments showed an increased frequency of chromosome aberrations in peripheral lymphocytes (23), and an increased mutagenic activity in the urine (31). These observations indicate that rubber workers are exposed to mutagenic substances in the work environment, and they are consistent with the epidemiologic findings of increased cancer risks. The cancer hazard in the rubber industry was evaluated by the International Agency for Research on Cancer in $1982(21)$.

A retrospective cohort study from two Swedish rubber manufacturing industries was initiated in the middle of the 1970s, and the results of a follow-up during the period 1961 to 1977 have been reported earlier (20). The cohort comprised 13114 individuals. Of these 2492 were unexposed office workers, included as an internal reference group. The preliminary results showed an excess of malignancies in the lungs, gastrointestinal organs, urinary bladder, and skin among the exposed workers, as well as an increased mortality from coronary heart disease. However, several risk excesses were also detected among the unexposed office workers, a finding that made the interpretation of the results somewhat complicated.

The follow-up of this cohort of rubber workers has now been extended prospectively and retrospectively to cover the time period 1952 to 1981 . Furthermore, 
the results have been analyzed with regard to employment time, latency period, calendar time, and the nationality of the cohort members.

\section{Subjects}

Company records were used as a source from which to gather information about the workers' personal identification number, name, exposure, employment period, and nationality at the time of first employment. All manufacturing workers, ie, workers in the weighing and mixing departments, calender workers, vulcanizers, pressing workers, tire builders, inspection and maintenance workers, cleaners, and storage handling workers, were included in the exposed group. All white-collar workers, ie, office workers and department heads, were included in the unexposed group. Persons changing their employment status from manufacturing worker to office worker were included in the exposed group, the change being accounted for in the calculation of exposure time.

The original cohort consisted of 14611 persons, also including those who were lost to follow-up. The following restrictions or corrections were applied to the cohort:

- Individuals with an employment time of less than one year were excluded.

- Individuals leaving'work before 1952 were excluded since follow-up was not possible via the national computerized registers before this year. However, many individuals started work several decades earlier.

- Personal identification numbers were checked, and duplicates in the registrations were corrected.

After these procedures the cohort consisted of 12212 persons ( 7932 men and 4280 women). The total number of person-years at risk in the exposed group was 179 894. At the start of employment 9105 individuals were Swedish citizens, and the rest were immigrants, mainly from the Nordic countries, Yugoslavia, and Greece.

\section{Methods}

The follow-up procedure included the matching of the personal identification numbers with computerized registers at the Swedish National Central Bureau of Statistics. Registers of the total living population, emigrations and immigrations since 1968, and deaths since 1952 were used. Mortality was investigated for the period 1952 to 1981 . Cancer cases in the cohort were identified for the period 1959-1980 by matching with the National Cancer Register. Individuals not traced in these registers were considered lost to follow-up and were excluded. Individuals who had emigrated were also excluded from the statistical analysis.

The number of deaths, cancer cases, emigrations, and individuals lost to follow-up are presented in ta-
Table 1. Vital status at the end of follow-up (31 December 1981).

\begin{tabular}{lccccc}
\hline Group & $\begin{array}{c}\text { Workers } \\
(\mathrm{N})\end{array}$ & $\begin{array}{c}\text { Deaths } \\
(\mathrm{N})\end{array}$ & $\begin{array}{c}\text { Cancers } \\
(\mathrm{N})\end{array}$ & $\begin{array}{c}\text { Emigra- } \\
\text { tions } \\
(\mathrm{N})\end{array}$ & $\begin{array}{c}\text { Lost to } \\
\text { follow-up } \\
(\mathrm{N})\end{array}$ \\
\hline $\begin{array}{l}\text { Exposed } \\
\quad \begin{array}{l}\text { Men } \\
\text { Women }\end{array}\end{array}$ & 6552 & 875 & 336 & 506 & 238 \\
$\begin{array}{l}\text { Unexposed } \\
\quad \text { Men }\end{array}$ & 1386 & 173 & 143 & 261 & 80 \\
$\quad$ Women & 1013 & 101 & 53 & 17 & 19 \\
\hline Total & 12212 & 1180 & 570 & 793 & 362 \\
\hline
\end{tabular}

ble 1. The proportion of individuals lost to follow-up was $3 \%$ (362 of 12212 persons). Among individuals with Swedish nationality the proportion was $1.2 \%$ (110 of 9105 persons).

The computation of expected values was based on national statistics for mortality and cancer incidence. The computations were performed according to the person-year method, counting man-years at risk specific for gender, calendar year, and five-year age class. The number of person-years in each stratum was multiplied with the disease rates in the corresponding stratum of the national statistics, and the number of expected cases was added over strata. The summary risk measure obtained was the standardized mortality (or morbidity) ratio (SMR) computed as (observed/expected) $\times 100$. Confidence limits for the SMR were computed with an exact method (28). Significance testing was based on the addition of probabilities derived from the Poisson distribution, and two-sided tests were used. Latency time was calculated as the time period from first employment until the start of risk calculation. The computations were performed with a computer program developed at the University of Linköping (1) for epidemiologic calculations.

Non-Swedish citizens at the time of first employment comprised $25 \%$ of the total; this level is higher than the national average. Since cause-specific mortality and incidence of cancer vary between ethnic groups, the majority of the statistical analyses were performed on the Swedish citizens in the cohort (tables 2-10). Mortality and incidence of cancer among the immigrants was analyzed separately (table 11).

Table 2. Observed $(O)$ and expected $(E)$ numbers of deaths, $1952-1981$. (SMR = standardized mortality ratio, $95 \% \mathrm{Cl}=$ $95 \%$ confidence interval for the SMR)

\begin{tabular}{lcccc}
\hline Group & O & E & SMR & $95 \% \mathrm{Cl}$ \\
\hline Exposed & & & & \\
$\quad$ Men & 798 & 904 & 88 & $82-94$ \\
$\quad$ Women & 158 & 220 & 71 & $61-83$ \\
Unexposed & & & & \\
$\quad$ Men & 97 & 132 & 73 & $59-89$ \\
$\quad$ Women & 31 & 37 & 83 & $56-117$ \\
\hline
\end{tabular}


Table 3. Mortality by cause among exposed male Swedish rubber workers. Risk calculation up to and including 79 years of age, latency requirement 10 years. $1 O=$ observed number of deaths, $E=$ expected number of deaths, $S M R=$ standardized mortality ratio, $95 \% \mathrm{Cl}=95 \%$ confidence interval for the SMR)

\begin{tabular}{|c|c|c|c|c|}
\hline Cause of deatha & 0 & $\mathrm{E}$ & SMR & $95 \% \mathrm{Cl}$ \\
\hline Malignant tumors, all (140-209) & 163 & 166.65 & 98 & $83-114$ \\
\hline $\begin{array}{l}\text { Esophagus (150) } \\
\text { Stomach (151) } \\
\text { Small and large intestine (152-153) } \\
\text { Rectum (154) } \\
\text { Liver (155) } \\
\text { Pancreas (157) } \\
\text { Lung (162) } \\
\text { Prostate (185) } \\
\text { Bladder (188) } \\
\text { Kidney (189) } \\
\text { Lymphoma and myeloma (200-203) } \\
\text { Leukemia (204-207) }\end{array}$ & $\begin{array}{r}1 \\
18 \\
10 \\
6 \\
4 \\
14 \\
32 \\
13 \\
4 \\
8 \\
8 \\
6\end{array}$ & $\begin{array}{r}3.55 \\
20.41 \\
12.35 \\
7.49 \\
3.56 \\
11.37 \\
29.91 \\
16.95 \\
5.33 \\
7.91 \\
8.92 \\
6.58\end{array}$ & $\begin{array}{r}28 \\
88 \\
81 \\
80 \\
112 \\
123 \\
107 \\
77 \\
75 \\
101 \\
90 \\
91\end{array}$ & $\begin{array}{r}0-156 \\
52-139 \\
38-148 \\
29-174 \\
30-287 \\
67-206 \\
73-151 \\
40-131 \\
20-192 \\
43-199 \\
38-176 \\
33-198\end{array}$ \\
\hline Circulatory diseases $(390-458)$ & 331 & 332.69 & 99 & $89-110$ \\
\hline $\begin{array}{l}\text { Ischemic heart disease }(410-414) \\
\text { Cerebrovascular disease }(430-438)\end{array}$ & $\begin{array}{r}232 \\
57\end{array}$ & $\begin{array}{r}238.66 \\
54.65\end{array}$ & $\begin{array}{r}97 \\
104\end{array}$ & $\begin{array}{l}85-110 \\
78-135\end{array}$ \\
\hline Respiratory diseases $(460-519)$ & 34 & 29.61 & 115 & $79-160$ \\
\hline Asthma, bronchitis and emphysema $(490-493)$ & 16 & 12.70 & 126 & $72-204$ \\
\hline Digestive diseases $(520-577)$ & 20 & 33.35 & 60 & $36-92$ \\
\hline Liver cirrhosis (571) & 5 & 13.24 & 38 & $12-88$ \\
\hline Genitourinary diseases $(580-607)$ & 5 & 12.25 & 41 & $13-95$ \\
\hline Nephritis and nephrosis $(581-584)$ & 3 & 4.72 & 64 & $13-185$ \\
\hline $\begin{array}{l}\text { External causes }(800-999) \\
\text { Other causes of death }\end{array}$ & $\begin{array}{l}62 \\
35 \\
\end{array}$ & $\begin{array}{l}75.36 \\
59.10 \\
\end{array}$ & $\begin{array}{l}82 \\
59 \\
\end{array}$ & $\begin{array}{r}63-105 \\
41-82 \\
\end{array}$ \\
\hline Total deaths $(0-999)$ & 650 & 709.01 & 92 & $84-99$ \\
\hline
\end{tabular}

a Code of the International Classification of Diseases, eighth revision, in parentheses.

Table 4. Observed $(O)$ and expected $(E)$ incidence of cancer, $1959-1980 .($ SMR $=$ standardized mortality ratio, $95 \% \mathrm{Cl}=$ $95 \%$ confidence interval for the SMR)

\begin{tabular}{lccrc}
\hline Group & $\mathrm{O}$ & $\mathrm{E}$ & SMR & $95 \% \mathrm{Cl}$ \\
\hline Exposed & & & & \\
$\quad$ Men & 299 & 291.8 & 102 & $91-114$ \\
$\quad$ Women & 126 & 139.2 & 91 & $75-107$ \\
Unexposed & & & & \\
$\quad$ Men & 52 & 44.6 & 117 & $87-152$ \\
$\quad$ Women & 38 & 29.8 & 128 & $90-174$ \\
\hline
\end{tabular}

\section{Results}

The observed total mortality was lower than the expected (table 2) due to the so-called "healthy worker effect." Cause-specific mortality was calculated for the exposed men (table 3 ). There was a slightly increased mortality from asthma, bronchitis, emphysema, and pancreatic cancer. None of these risk elevations was statistically significant.

The total cancer incidence corresponded well with the expected (table 4). Site-specific cancer incidence was calculated for the exposed men (table 5). No significant risk excesses were observed.

In the analysis of the mortality and incidence of cancer during different time periods after first employment (table 6), the SMR values for total numbers of deaths, coronary heart disease, and total cancer incidence increased with increasing follow-up time. There was a significantly increased incidence of lung cancer
Table 5. Cancer incidence by site among exposed male Swedish rubber workers, 1959-1980. Risk calculation up to and including age 79 years, latency requirement 10 years. $(0$ $=$ observed number of cases, $E=$ expected number of cases, SMR = standardized mortality ratio, $95 \% \mathrm{Cl}=95 \%$ confidence interval for the SMR)

\begin{tabular}{|c|c|c|c|c|}
\hline Site of tumora & 0 & $\mathrm{E}$ & SIMR & $95 \% \mathrm{Cl}$ \\
\hline asopharynx (146) & - & 0.67 & 0 & $0-553$ \\
\hline & 1 & & 30 & \\
\hline oma & 20 & 20.57 & 97 & $59-150$ \\
\hline lo & 15 & 17.41 & 86 & $48-142$ \\
\hline $\operatorname{ver}(15$ & 7 & 5.96 & 117 & $17-242$ \\
\hline (157) & 11 & 9. & 114 & $56-204$ \\
\hline sinuses $(160)$ & 1 & 0.8 & 125 & $3-697$ \\
\hline Lary & 5 & 3. & 143 & $46-334$ \\
\hline ra (162) & 32 & 28.89 & 111 & $75-156$ \\
\hline & 34 & 41. & 82 & $57-115$ \\
\hline Kid & 12 & 12.1 & 99 & $51-173$ \\
\hline Bladder (181) & 17 & 16.25 & 105 & $60-167$ \\
\hline ( & 6 & 5.8 & 101 & $37-219$ \\
\hline nonmelanoma (191) & 7 & 6.4 & 108 & $43-222$ \\
\hline רa (197) & 1 & 1.96 & 51 & $1-284$ \\
\hline & 5 & 3.90 & 128 & $41-299$ \\
\hline & 7 & 7.4 & 94 & $37-193$ \\
\hline Other site & 76 & 60.90 & 124 & $98-156$ \\
\hline All siles $(140-20$ & 257 & 247.06 & 104 & $91-117$ \\
\hline
\end{tabular}

a Code of the International Classification of Disease, seventh revision, in parentheses.

after 40 years or more since first employment. The SMR for asthma, bronchitis, and emphysema fluctuated, the risk during follow-up between 20 and 40 years after first employment being nearly statistically significant $[95 \%$ confidence interval $(\mathrm{CI})$ for the SMR 
Table 6. Mortality and cancer incidence by time since first employment. Risk calculation up to and including 79 years of age. (SMR = standardized mortality ratio)

\begin{tabular}{|c|c|c|c|c|c|c|c|c|c|c|}
\hline & \multicolumn{10}{|c|}{ Time since first employment (years) } \\
\hline & \multicolumn{2}{|c|}{$\leq 9$} & \multicolumn{2}{|c|}{$10-19$} & \multicolumn{2}{|c|}{$20-29$} & \multicolumn{2}{|c|}{$30-39$} & \multicolumn{2}{|c|}{$\geq 40$} \\
\hline & Number & SMR & Number & SMR & Number & SMR & Number & SMR & Number & SMR \\
\hline Total deaths & 66 & 59 & 168 & 81 & 214 & 94 & 125 & 83 & 143 & 114 \\
\hline Ischemic heart disease & 16 & 66 & 40 & 67 & 79 & 101 & 52 & 96 & 61 & 126 \\
\hline emphysema & 2 & 133 & 3 & 94 & 8 & 194 & 5 & 173 & - & 0 \\
\hline Cancer incidence & 27 & 93 & 64 & 90 & 77 & 94 & 59 & 113 & 57 & $133^{*}$ \\
\hline $\begin{array}{l}\text { Lung cancer } \\
\text { Pancreatic cancer } \\
\text { Bladder cancer }\end{array}$ & $\begin{array}{r}- \\
3 \\
2\end{array}$ & $\begin{array}{r}0 \\
283 \\
121\end{array}$ & $\begin{array}{l}5 \\
3 \\
2\end{array}$ & $\begin{array}{r}64 \\
113 \\
69\end{array}$ & $\begin{array}{l}8 \\
4 \\
6\end{array}$ & $\begin{array}{r}83 \\
126 \\
110\end{array}$ & $\begin{array}{l}5 \\
2 \\
7\end{array}$ & $\begin{array}{r}79 \\
96 \\
196\end{array}$ & $\begin{array}{r}14 \\
2 \\
1\end{array}$ & $\begin{array}{c}274^{*} \\
116 \\
35\end{array}$ \\
\hline
\end{tabular}

* $p<0.05$.

Table 7. Mortality and cancer incidence by employment time. Risk calculation up to and including 79 years of age, latency requirement 40 years. $(S M R=$ standardized mortality ratio).

\begin{tabular}{|c|c|c|c|c|c|c|}
\hline & \multicolumn{6}{|c|}{ Employment time (years) } \\
\hline & \multicolumn{2}{|c|}{$<20$} & \multicolumn{2}{|c|}{$20-29$} & \multicolumn{2}{|c|}{$\geq 30$} \\
\hline & Number & SMR & Number & SMR & Number & SMR \\
\hline Total deaths & 21 & 105 & 12 & 112 & 110 & 116 \\
\hline $\begin{array}{l}\text { Circulatory diseases } \\
\text { Ischemic heart disease }\end{array}$ & $\begin{array}{l}8 \\
5\end{array}$ & $\begin{array}{l}74 \\
63\end{array}$ & $\begin{array}{l}6 \\
5\end{array}$ & $\begin{array}{l}103 \\
114\end{array}$ & $\begin{array}{l}71 \\
51\end{array}$ & $\begin{array}{l}141^{*} \\
142^{*}\end{array}$ \\
\hline Cancer incidence & 10 & 149 & 7 & 186 & 40 & 124 \\
\hline Lung cancer & 3 & 366 & 2 & 417 & 9 & $236^{*}$ \\
\hline
\end{tabular}

* $p<0.05$.

Table 8. Mortality among workers in the weighing and mixing departments, $1952-1981$, as divided into two subgroups. Risk calculation up to and including 79 years of age. (SMR = standardized mortality ratio).

\begin{tabular}{|c|c|c|c|c|}
\hline \multirow{2}{*}{ Cause of death ${ }^{2}$} & \multicolumn{2}{|c|}{ Subgroup $1^{\mathrm{b}}$} & \multicolumn{2}{|c|}{ Subgroup $2^{\mathrm{c}}$} \\
\hline & Number & SMR & Number & SMR \\
\hline Malignant tumors, all (140-209) & 25 & 100 & 14 & 126 \\
\hline $\begin{array}{l}\text { Esophagus (150) } \\
\text { Stomach }(151) \\
\text { Small and large intestine (152-153) } \\
\text { Rectum (154) } \\
\text { Liver (155) } \\
\text { Pancreas (157) } \\
\text { Lung (162) } \\
\text { Prostate (185) } \\
\text { Bladder (188) } \\
\text { Kidney (189) } \\
\text { Lymphoma and myeloma (200-203) } \\
\text { Leukemia (204-207) }\end{array}$ & $\begin{array}{r}- \\
3 \\
2 \\
1 \\
- \\
2 \\
5 \\
2 \\
2 \\
2 \\
2 \\
-\end{array}$ & $\begin{array}{r}0 \\
96 \\
107 \\
87 \\
0 \\
116 \\
109 \\
71 \\
235 \\
173 \\
156 \\
0\end{array}$ & $\begin{array}{l}- \\
2 \\
2 \\
- \\
- \\
4 \\
2 \\
1 \\
1 \\
-\end{array}$ & $\begin{array}{r}0 \\
141 \\
240 \\
0 \\
0 \\
0 \\
197 \\
0 \\
524 \\
192 \\
57 \\
0\end{array}$ \\
\hline $\begin{array}{l}\text { Circulatory diseases }(390-458) \\
\text { Ischemic heart disease }(410-414) \\
\text { Cerebrovascular disease }(430-438)\end{array}$ & $\begin{array}{r}55 \\
44 \\
7\end{array}$ & $\begin{array}{r}106 \\
118 \\
83\end{array}$ & $\begin{array}{r}30 \\
22 \\
5\end{array}$ & $\begin{array}{l}130 \\
132 \\
133\end{array}$ \\
\hline Respiratory diseases $(460-519)$ & 5 & 111 & 3 & 150 \\
\hline Asthma, bronchitis and emphysema $(490-493)$ & 1 & 51 & 1 & 115 \\
\hline Digestive diseases $(520-577)$ & 3 & 66 & 2 & 99 \\
\hline Liver cirrhosis $(571)$ & - & 0 & - & 0 \\
\hline Genitourinary diseases $(580-607)$ & 1 & 54 & 1 & 120 \\
\hline Nephritis and nephrosis $(581-584)$ & 1 & 154 & 1 & 341 \\
\hline $\begin{array}{l}\text { External causes }(800-999) \\
\text { Other causes of death } \\
\end{array}$ & $\begin{array}{l}8 \\
5 \\
\end{array}$ & $\begin{array}{r}101 \\
72 \\
\end{array}$ & $\begin{array}{l}2 \\
4 \\
\end{array}$ & $\begin{array}{r}58 \\
112 \\
\end{array}$ \\
\hline Total deaths $(0-999)$ & 102 & 98 & 56 & 122 \\
\hline
\end{tabular}

a Code of the International Classification of Diseases, eighth revision, in parentheses.

b Subgroup 1 had an exposure time of one year or more, a latency of at least 10 years, and no restriction on time of first employment.

c Subgroup 2 had an exposure time of five years or more, a latency of at least 20 years, and first employment before 1951. 
being 98-388]. The number of cases of pancreatic cancer and bladder cancer was small, the SMR fluctuated, and there was no time trend.

For a further evaluation of the observed risk excesses the relation between exposure time and SMR was investigated, with a latency requirement of 40 years

Table 9. Incidence of cancer among workers in the weighing and mixing departments, $1959-1980$, as divided into two subgroups. Risk calculation up to and including 79 years of age. $(\mathrm{SMR}=$ standardized mortality ratio)

\begin{tabular}{lrrrrr}
\hline \multirow{2}{*}{ Site of tumor } & \multicolumn{2}{c}{ Subgroup $1^{\mathrm{b}}$} & & \multicolumn{2}{c}{ Subgroup 2 } \\
\cline { 2 - 3 } \cline { 5 - 6 } & Number SMR & & \multicolumn{2}{c}{ Number SMR } \\
\hline Nasoparynx (146) & - & 0 & & - & 0 \\
Esophagus (150) & - & 0 & & - & 0 \\
Stomach (151) & 3 & 94 & & 142 \\
Colon (153) & 2 & 77 & & 174 \\
Liver (155) & 1 & 107 & & 0 \\
Pancreas (157) & 1 & 67 & & - & 0 \\
Nose and sinuses (160) & - & 0 & & 0 \\
Larynx (161) & 1 & 197 & & 0 \\
Lung, pleura (162) & 5 & 113 & & 204 \\
Prostate (177) & 5 & 72 & & 2 & 66 \\
Kidney (180) & 3 & 174 & & 259 \\
Bladder (181) & 4 & 164 & & 4 & $368^{*}$ \\
Multiple myeloma (203) & 1 & 168 & & 1 & 379 \\
Leukemia (204-207) & 1 & 94 & & - & 0 \\
Other sites & 10 & 124 & & 6 & 168 \\
\hline All sites (140-209) & 37 & 101 & & 23 & 141 \\
\hline
\end{tabular}

a Code of the International Classification of Diseases, seventh revision, in parentheses.

b Subgroups as in table 8.

${ }^{*} p<0.05$.

Table 10. Mortality and incidence of cancer by time of first employment. Risk calculation up to and including 79 years of age, latency requirement 10 years. (SMR $=$ standardized mortality ratio).

\begin{tabular}{lrrrrr}
\hline & \multicolumn{3}{c}{ First employment } \\
\cline { 2 - 3 } & \multicolumn{3}{c}{ Before 1951} & & \multicolumn{2}{c}{ 1951 or later } \\
\cline { 2 - 3 } \cline { 5 - 6 } & Number & SMR & & Number & SMR \\
\cline { 2 - 6 } & 434 & 88 & & 216 & 101 \\
Total deaths & 11 & 125 & & 5 & 128 \\
Ischemic heart disease & 167 & 100 & & 65 & 91 \\
Asthma, bronchitis and & & & & \\
emphysema & 177 & 104 & & 80 & 104 \\
Cancer incidence & 25 & 124 & & 7 & 80 \\
Lung cancer & 7 & 102 & & 4 & 142 \\
Pancreatic cancer & 12 & 103 & & 5 & 98 \\
Bladder cancer & & &
\end{tabular}

(table 7). The mortality from diseases of the circulatory system was positively correlated to duration of exposure. An increased incidence of lung cancer was observed in all three exposure-time categories, but the SMR was significantly raised only among those exposed for at least 30 years. The time trend could not be evaluated because of the small number of observed cases.

A group of exposed individuals had worked in the weighing and mixing departments, "mixers." The SMR was computed for mixers with a latency requirement of 10 years (subgroup 1) and for a subgroup first employed before 1951, exposed more than five years, and with a latency requirement of 20 years (subgroup 2) (table 8). The latter subgroup was more heavily exposed since the exposure time was longer and the exposure occurred in a time period when dust control was less developed. The SMR was higher among the more heavily exposed for a majority of the causes of death, but it was not significantly raised for any of the studied diagnoses. The cancer incidence for the mixers is presented in table 9. Again the SMR was higher in the more highly exposed group when compared to that of all mixers. Four cases of bladder cancer were observed versus 1.08 expected, corresponding to an SMR of $368(\mathrm{p}<0.05)$.

The mortality and cancer incidence by time of first employment was analyzed (table 10). There was an excess of lung cancer only among those employed before 1951. However, it should be pointed out that this is another reflection of the findings in the latency time analysis (table 6), since only those first employed before 1941 had a latency of 40 years within the study period, and therefore they were all included among those first employed before 1951 .

Among the office workers, an increased incidence of tumors of the lung and larynx was found (11 observed versus 4.46 expected lung tumors and 3 observed versus 0.59 expected cases of laryngeal cancer). However, no relation to latency from first employment was found in this group, in contrast to the exposed group.

The mortality and incidence of cancer among the exposed male immigrants was analyzed (table 11). The Swedish national statistics were used as a reference, and the results must be interpreted with caution since ethnic factors, as well as occupational exposures, may

Table 11. Mortality and incidence of cancer among immigrants by citizenship at time of employment. Swedish national statistics used as reference. Risk calculation up to and including 79 years of age.

\begin{tabular}{|c|c|c|c|c|c|c|c|c|}
\hline & \multicolumn{2}{|c|}{ Finnish } & \multicolumn{2}{|c|}{ Danish } & \multicolumn{2}{|c|}{ Yugoslavian } & \multicolumn{2}{|c|}{ Other } \\
\hline & Number & SMR & Number & SMR & Number & SMR & Number & SMR \\
\hline Total deaths & 31 & $193^{*}$ & 16 & 86 & 6 & 83 & 26 & 98 \\
\hline $\begin{array}{l}\text { Circulatory diseases } \\
\text { Violent death and }\end{array}$ & 8 & 179 & 4 & 54 & 1 & 61 & 12 & 117 \\
\hline intoxication & 13 & $228^{*}$ & 1 & 28 & 4 & 140 & 4 & 77 \\
\hline Cancer incidence & 8 & 151 & 13 & $194^{*}$ & 3 & 130 & 10 & 109 \\
\hline Lung cancer & 3 & $633^{*}$ & 4 & $526^{*}$ & - & 0 & 2 & 199 \\
\hline
\end{tabular}

$\star p<0.05$. 
have influenced the results. Immigrants from Finland had an increased total mortality, an increased risk for violent death, and an increased lung cancer incidence. Immigrants from Denmark had a raised cancer incidence and lung cancer incidence. Immigrants from Yugoslavia and other immigrant groups did not exhibit significant excess risks.

\section{Discussion}

There was no significantly increased mortality or cancer incidence among the rubber workers when the cohort was analyzed without regard to latency or exposure time. However, the mortality from coronary heart disease and the incidence of lung cancer was increased when 40 years had elapsed since first employment. The SMR for coronary heart disease correlated positively with employment time. The finding of a dose-response relationship indicates that the risk excess was due to occupational factors. An increased risk for coronary heart disease was reported in two earlier studies $(2,26)$, but has not been found in the majority of studies on rubber workers.

The finding of a risk excess only after more than 40 years since first employment may be interpreted in the following two ways: first, the causative agent might not have been present after 1940, and, second, the toxic agent might take four decades or more to manifest its effect as increased mortality. A median latency time of 38.5 years was described for lung cancer caused by exposure to asbestos (4), and a similar relationship between lung cancer and rubber work is possible. No definite conclusions can be drawn on this point, and it remains unknown if the causative factor has been present in more recent time periods or not.

The mortality from asthma, bronchitis, and emphysema (ICD 490-493) was increased in the time period 20-40 years after first employment. The increase was of borderline statistical significance. An increased frequency of chronic bronchitis and reduced pulmonary function was earlier reported among rubber workers $(11,12,13)$, but increased mortality from lung diseases has not been reported earlier.

Bladder cancer is well documented as an occupational cancer hazard among rubber workers. In this study, a risk excess was found only among individuals who had worked in the weighing and mixing departments before 1951. Similar results were obtained in a case-referent study from the rubber industry in the United States, where an excess risk of bladder cancer was noted especially among workers in a mixing department and among calender workers (7). It seems probable that the special exposure conditions in these departments are related to the bladder cancer excess, especially since an increased mutagenic activity in urine has been found among workers in mixing departments (31). However, excess risks for bladder cancer may exist also in other departments, even if not detected in this study.
The present results, obtained after an extension of the follow-up period to 1952-1981, differ on some points from the earlier report covering the time period 1961-1977 (20). The proportion of individuals lost to follow-up has been reduced by the restrictions made with regard to nationality, employment time, and employment period. Increased frequencies of liver and pancreas tumors and of malignant melanomas were observed among the exposed workers in the earlier report. After the extension of the follow-up period no excess risks were noted for these tumor sites. The excess risk for respiratory malignancies observed among unexposed men was unaffected by the extension. The exposure classification was rechecked and found to be correct. The excess remains unexplained, but could partially be due to smoking habits.

The number of observed cases of leukemia corresponded well with the number expected; this finding contrasts with the results of several American studies of rubber workers. Benzene was earlier used as a solvent in the rubber industry but was abandoned in the Swedish industry before 1950 . It seems as if benzene has been used in more recent years in the American rubber industry (22), and its use could explain the epidemiologic finding.

The analysis of mortality and cancer incidence among the immigrants revealed some high excess risks. Immigrants from Finland had an increased total mortality and an increased incidence of lung cancer and violent deaths. It should be pointed out that the Swedish national statistics were used as reference. Therefore, the results reflect a combination of occupational and ethnic factors. Regarding the first, it is possible that the immigrants got the "worst" jobs and therefore had a higher exposure. However, no corresponding risk excesses were observed for immigrants from non-Scandinavian countries. Regarding the latter, the Finnish population has a higher incidence of lung cancer (33) and coronary heart disease (35) than the Swedish population, and the increased risks can, to a large extent, be explained by ethnic factors. Since no individual exposure data are available, this question remains unanswered, but the results are important from a methodological point and show that the ethnic composition of a cohort must be accounted for in the analysis.

The cohort comprised individuals of different job categories and, with the exception of mixers, a jobspecific analysis was not possible. Additional excess risks, related to uncommon exposure factors, cannot be ruled out. The conclusions that can be drawn concerning the risks associated with the present exposure situation in the rubber industry are limited. Exposure levels have been reduced in comparison to the situation in the 1930s and 1940s. The long latency time for the diseases under study makes it impossible to evaluate epidemiologically the effects of exposures during more recent decades. However, the results from gen- 
otoxicologic investigations made during recent years corroborate the epidemiologic findings and indicate that a further reduction of exposure is warranted.

\section{Acknowledgments}

We thank Dr A Englund, Dr K Gumaelius, Mr L Holmlund, Dr L Kestrup, Mr R Maasing, Dr G Molina, and Dr P Westerholm who have contributed to the study at different stages. Ms A Gustavsson skillfully assisted with the data analysis.

The study was supported by a grant from the Swedish National Board of Occupational Safety and Health.

\section{References}

1. Andersson K, Anjou CG, Brodin G, Kling H, Samuelsson P-J. EPILIN: Datain, ratin, cohort, search, stat: Datorprogram för kohortstudier. Användarhandledning. (EPILIN: Datain, Ratin, Cohort, Search, Stat: Computer program for cohort studies. User manual). University of Linköping, Linköping 1982.

2. Andjelkovich D, Taulbee J, Blum S. Mortality of female workers in a rubber manufacturing plant. J Occup Med 20 (1978) 409-413.

3. Andjelkovich D, Taulbee J, Symons M. Mortality experience of a cohort of rubber workers, 1964-73. J Occup Med 18 (1976) 387-394.

4. Armenian HK, Lilienfield AM. The distribution of incubation periods of neoplastic disease. Am J Epidemiol 99 (1974) $92-100$.

5. Baxter PJ, Werner JB. Mortality in the British rubber industries 1967-76. Her Majesty's Stationery Office, London 1980.

6. Case RAM, Hosker ME. Tumour of the urinary bladder as an occupational disease in the rubber industry in England and Wales. Br J Prev Soc Med 8 (1954) 39-50.

7. Checkoway H, Smith AH, McMichael AJ, Jones FS, Monson RR, Tyroler HA. A case-control study of bladder cancer in the United States rubber and tyre industry. Br J Ind Med 38 (1981) 240-246.

8. Delzell E, Monson RR. Mortality among rubber workers: III Cause-specific mortality 1940-78. J Occup Med 23 (1981) 667-684.

9. Delzell E, Monson RR. Mortality among rubber workers: X Reclaim workers. Am J Ind Med 7 (1985) $307-313$.

10. Donner M, Husgafvel-Pursiainen K, Jenssen D, Rannug $\mathrm{A}$. Mutagenicity of rubber additives and curing fumes: Results from five short-term bioassays. Scand J Work Environ Health 9 (1983): suppl 2, 27-37.

11. Fine LJ, Peters JM. Respiratory morbidity in rubber workers: I Prevalence of respiratory symptoms and disease in curing workers. Arch Environ Health 31 (1976) 5-9.

12. Fine LJ, Peters JM. Respiratory morbidity in rubber workers: II Pulmonary function in curing workers. Arch Environ Health 31 (1976) 10-14.

13. Fine LJ, Peters JM. Studies of respiratory morbidity in rubber workers: III Respiratory morbidity in processing workers. Arch Environ Health 31 (1976) 136-140.

14. Fox AJ, Collier PF. A survey of occupational cancer in the rubber and cablemaking industries: Analysis of deaths occurring in 1972-74. Br J Ind Med 33 (1976) $249-264$.

15. Fox AJ, Lindars DC, Owen R. A survey of occupational cancer in the rubber and cablemaking industries: Results of five-year analysis, 1967-71. Br J Ind Med 31 (1974) 140-151.
16. Goldsmith DF, Smith AH, McMichael AJ. A casecontrol study of prostate cancer within a cohort of rubber and tire workers. J Occup Med 22 (1980) 533-541.

17. Hedenstedt A, Ramel C, Wachtmeister C $\mathbf{A}$. Mutagenicity of rubber vulcanization gases in Salmonella typhimurium. J Toxicol Environ Health 8 (1981) 805-814.

18. Hedenstedt A, Rannug U, Ramel C, Wachtmeister CA. Mutagenicity and metabolism studies on 12 thiuram and dithiocarbamate compounds used as accelerators in the Swedish rubber industry. Mutation Res 68 (1979) $313-325$.

19. Holmberg B, Sjöström B. Toxicological aspects of chemical hazards in the rubber industry. $\mathrm{J}$ Toxicol Environ Health 6 (1980) 1201-1209.

20. Holmberg B, Westerholm P, Maasing R, Kestrup L, Gumaelius K, Holmlund L, Englund A. Retrospective cohort study of two plants in the Swedish rubber industry. Scand J Work Environ Health 9 (1983): suppl 2, 59-68.

21. International Agency for Research on Cancer. The rubber industry. Lyon 1982. (IARC monographs on the evaluation of carcinogenic risk of chemicals to humans, volume 28 ).

22. International Agency for Research on Cancer. Some industrial chemicals and dyestuffs. Lyon 1982. (IARC monographs on the evaluation of carcinogenic risk of chemicals to humans, volume 29).

23. Mäki-Paakkanen J, Sorsa M, Vainio H. Sister chromatid exchanges and chromosome abberations in rubber workers. Teratogenesis Carcinog Mutagenesis 4 (1984) 189-200.

24. McMichael AJ, Andjelkovich DA, Tyroler HA. Cancer mortality among rubber workers: An epidemiologic study. Ann NY Acad Sci 271 (1976) 125-137.

25. McMichael AJ, Spirtas R, Gamble JF, Kupper LL. Solvent exposure and leukemia among rubber workers: An epidemiologic study. J Occup Med 17 (1975) 234-239.

26. McMichael AJ, Spirtas R, Gamble JF, Tousey PM. Mortality among rubber workers: Relationship to specific jobs. J Occup Med 18 (1976) 178-185.

27. Monson RR, Fine LJ. Cancer mortality and morbidity among rubber workers. J Natl Cancer Inst 61 (1978) 1047-1053.

28. Mulder PGH. An exact method for calculating a confidence interval of a poisson parameter. Am J Epidemiol 117 (1983) 377.

29. Norell S, Ahlbom A, Lipping H, Österblom L. Oesophageal cancer and vulcanisation work. Lancet 1 (1983) 462-463.

30. Parkes, Veys CA, Waterhouse JAH, Peters A. Cancer mortality in the British rubber industry. $\mathrm{Br} \mathrm{J}$ Ind Med 39 (1982) 209-220.

31. Sorsa M, Falck K, Mäki-Paakkanen J, Vainio H. Genotoxic hazards in the rubber industry. Scand J Work Environ Health 9 (1983) 103-107.

32. Veys $\mathrm{C}$. Two epidemiological inquiries into the incidence of bladder tumours in industrial workers. J Natl Cancer Inst 43 (1969) 219-226.

33. Waterhouse J, Muir C, Correa P, Powell J, ed. Cancer incidence in five continents. Volume III. International Agency for Research on Cancer, Lyon 1976. (IARC scientific publication no 15).

34. Waterhouse JAM. Current status of cancer risk in the rubber industry. In: Birch JM, ed. Proceedings of the 12th International Cancer Congress, Buenos Aires 1978: Advances in medical oncology, research and education. Volume III (Epidemiology). Pergamon Press, Oxford 1979.

35. World Health Organization, Regional Office for Europe. Public health in Europe: 5. Myocardial infarction, community registers. Copenhagen 1976.

Received for publication: 4 July 1986. 